\title{
Enhancing Anaerobic Digestion: The Effect of Carbon Conductive Materials
}

\author{
Judith González, Marta E. Sánchez and Xiomar Gómez *D \\ Chemical and Environmental Bioprocess Engineering Group, Natural Resources Institute (IRENA), \\ Universidad de León, Av. de Portugal 41, 24009 León, Spain; jgonza@unileon.es (J.G.); \\ mesanm@unileon.es (M.E.S.) \\ * Correspondence: xagomb@unileon.es; Tel.: +34-987-291-845
}

Received: 27 September 2018; Accepted: 29 October 2018; Published: 1 November 2018

\begin{abstract}
Anaerobic digestion is a well-known technology which has been extensively studied to improve its performance and yield biogas from substrates. The application of different types of pre-treatments has led to an increase in biogas production but also in global energy demand. However, in recent years the use of carbon conductive materials as supplement for this process has been studied resulting in an interesting way for improving the performance of anaerobic digestion without greatly affecting its energy demand. This review offers an introduction to this interesting approach and covers the different experiences performed on the use of carbon conductive materials proposing it as a feasible alternative for the production of energy from biomass, considering also the integration of anaerobic digestion and thermal valorisation.
\end{abstract}

Keywords: improving biogas yields; biochar supplementation; direct interspecies electron transfer; integrating pyrolysis-digestion

\section{Introduction}

Fossil fuels (coal, oil and natural gas) have been the conventional sources of energy that keep running the modern world. Yet, these fuels are finite and are a cause of great impact on the environment with relevant effects on climate change [1]. This has made the search for sustainable alternatives even more important-sources capable of producing renewable energy but also being economically feasible. Among these different processes, the conversion of biomass into biofuels plays a crucial role. The production of ethanol and biodiesel are just an example of the processes most widely applied for producing biofuels. On the other hand, anaerobic digestion is capable of generating biogas which can either be used directly or converted into energy by the use of a combined heat and power (CHP) unit, the process also produces stabilised organic material as a by-product which can be valorised as an organic amendment. This digested material is a nutrient-rich sludge which can serve as a fertiliser, if it is well handled by proper application operation and control of heavy metals in soils [2].

However, land spreading of digestates for agricultural purposes has been progressively restricted and often legally banned, with several difficulties when a proper way of final disposal is needed. In recent years, new ways of valorisation have been searched as it is the concatenation of the anaerobic digestion with thermal processes as pyrolysis units, using the digestate as input material of this latter process and generating as main products: pyrolysis gases, bio-oils and biochars [3,4]. Other ways of valorisation are the use of digestastes as nutrient media for the culture of plant growth promoting microorganisms in an attempt to convert this digested material into a high value added product [5].

Anaerobic digestion is a well-known technology widely applied for the valorisation of high organic strength wastes. The process has been subjected to extensive research to increase the efficiency of the degradation and biogas yields. This technology has been traditionally applied in the treatment of 
sewage sludge, chemical effluents, agricultural and livestock wastes, and has been extensively studied in an attempt to improve performance and overcome several difficulties frequently encountered when dealing with complex residues, including inhibitory conditions caused by toxic intermediaries, difficult assimilation of lignocellulosic material, and low assimilation rate of acid compounds.

In the present review, a description of the process and the different approaches for increasing biogas yields is presented, with special focus on the performance of the digestion when carbon conductive materials are used for favouring biomass proliferation and increasing degradation rates.

\section{Fundamental Aspects of the Anaerobic Digestion Process}

Anaerobic digestion is a complex process where a diverse group of microorganisms are involved in the sequential conversion of organic matter. In general, the process can be divided into four main steps: hydrolysis, acidogenesis, acetogenesis and methanogenesis in which hydrolytic, fermentative bacteria, acetogens and methanogens play distinct roles [1]. A schematic representation of the different phases of the digestion process is shown in Figure 1. The first stage is usually regarded as the limiting phase, being a process characterised by surface and transport phenomena in close relationship with the biomass activity or concentration. The hydrolysis stage is carried out by extra-cellular enzymes secreted by fermentative microorganisms which are responsible of the conversion of complex substrates such as particulate carbohydrates, proteins and lipids, into soluble components. Among these compounds, volatile fatty acids and $\mathrm{H}_{2}$ are formed which serve as precursors of biogas reactions [6].

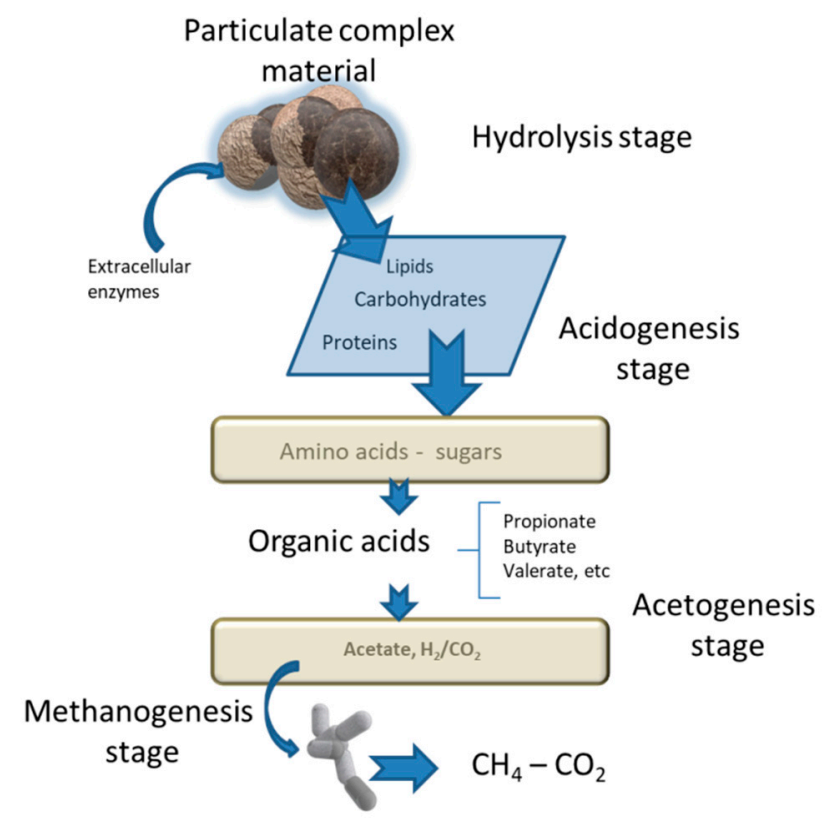

Figure 1. Schematic representation of the different stages of the anaerobic digestion process adapted from [1]. Organic matter is transformed into methane by a series of sequential microbiological reactions.

High levels of volatile fatty acids (VFAs) in the reactor may cause a decrease of process $\mathrm{pH}$ when the alkalinity level is not enough, resulting in a process failure. However, changes in VFA concentration in the digester do not necessarily induce a significant change in the reactor microbial population [7]. Short chain fatty acids, of a number of carbons greater than two, are traditionally monitored during the digestion process since they serve along with $\mathrm{pH}$ as an indication of the presence of imbalance of the process. Nonetheless, these changes should be properly interpreted as the result of process imbalance and not the cause of inhibition [8]. In addition, defining a proper level of VFA to be kept in a "healthy" anaerobic reactor is not an easy task, as different systems have their own "normal" levels of VFAs that can be considered as a cause of instability in a completely differing anaerobic reactor but not cause any problem in the other [9]. 
VFAs have been reported to cause inhibition of the cellulolytic activity at concentrations greater than $2 \mathrm{~g} / \mathrm{L}$, and therefore of the rate of cellulose hydrolysis, whereas glucose degradation seems to be more tolerant to the presence of high levels of these acids [10]. Propionic acid has been reported to have a significant inhibitory effect at concentrations much lower than those reported for acetic or butyric acid $(900 \mathrm{mg} / \mathrm{L}$ of propionic acid for observing negative effects, versus values of $2400 \mathrm{mg} / \mathrm{L}$ for acetic and $1800 \mathrm{mg} / \mathrm{L}$ for butyric acid [11]). However, the presence of propionic acid itself as a consequence of the metabolism of the substrate does not necessarily exert a negative influence on the performance of the process.

Pullammanappallil and co-workers [12] reported on stable operation of a digester treating phenol. Propionic acid was formed from the metabolism of this compound, reaching levels of $2750 \mathrm{mg} / \mathrm{L}$. The digester continued to convert all the glucose, which was also supplied to methane, showing that propionic acid accumulation to such high values did not inhibit the conversion of glucose to methane. Therefore, propionic acid accumulation may be an effect and not a cause of inhibition of the anaerobic digestion process. In a similar way, Fierro et al. [13] reported on stable performance of a high loaded reactor treating swine manure and glycerine as co-substrate. In this case, the propionic concentration reached values greater than $5000 \mathrm{mg} / \mathrm{L}$ and its accumulation was explained by the fastest rate of glycerol degradation, which was higher than that of propionate consumption; thus, accumulation of the acid was to be expected [14].

The transformation of organic acids with a number of carbons greater than two is the next stage in this complex transformation process. Acetogenic organisms produce acetate from organic acids, and waste electrons as hydrogen. This hydrogen is converted by hydrogenotrophic methanogens, while the acetic acid is converted to methane by aceticlastic methanogens [15]. The acetotrophic methanogens can compete with the acetate oxidizing bacteria which in time convert acetate to hydrogen and carbon dioxide, or they can also use the reverse reaction to produce acetate. At high hydrogen content (e.g., $\geq 500 \mathrm{~Pa}$ ) acetogenesis is favoured whereas at low hydrogen content $(\leq 40 \mathrm{~Pa})$, the oxidation of acetate takes place [16].

The final stage involves the production of methane. Methanogens are the microorganisms that produce methane as the end-product of their anaerobic respiration; they are strictly anaerobic archaea belonging to the Euryarchaeota with a restricted capacity for utilizing substrates: $\mathrm{CO}_{2}$, methyl-group containing compounds and acetate [17]. The use of $\mathrm{CO}_{2}$ as main substrate necessarily involves $\mathrm{H}_{2}$ electron donor, thus type of methanogens are called hydrogenotrophs. Methanosaeta species can convert acetate to methane but are unable to use hydrogen or formate as an electron donor for producing methane from carbon dioxide [18]. It is surprising that only two genera Methanosaeta and Methanosarcina are capable of assimilating the major intermediary of the digestion process (acetate) and are also responsible for at least two-thirds of the biologically generated methane [17].

The balance of the different stages in the anaerobic digestion process has been usually explained based on the levels of hydrogen in the reactor, with low levels of this gas being considered necessary to make the conversion into methane thermodynamically favourable [19]. The exchange of hydrogen between syntrophs and methanogens is a delicate step and any disruption may cause the accumulation of this gas and a subsequent build-up in VFA. However, other mechanisms for the transfer of electrons between different species have been proposed recently, based on experimental work with pure cultures and mixed microflora where hydrogen or formate were not available as electron carriers to explain the methane yields of the system [20-22].

\section{Improving the Performance of the Anaerobic Digestion Process}

The intrinsic complexity of the digestion process is associated with the diverse groups of microorganisms involved and the strict balance that should be kept between the different stages. For this reason, improving degradation rates of complex substrates has been traditionally associated with the application of pre-treatments whereas the balance of nutrients has been traditionally attempted 
with the addition of co-substrates for avoiding accumulation of toxic intermediaries and increase biogas yields.

The enhancement of the digestion process has been performed using different approaches. The most studied in literature cover the application of pre-treatments to facilitate the hydrolysis of the organic material. Figure 2 represents some of the different pre-treatments available and some of their possible combinations for increasing the efficiency of the solubilisation and disruption of the organic compounds. Thermal and microwave pre-treatments, the use of alkaline and acid media, mechanical (ultrasound, high pressure and lysis) chemical oxidation and electrooxidation, as well as the combination of the above processes, are just some examples of the wide variety of developed processes intended for improving the degradation rate of the substrates [23-25]. An extensive review of the different available pre-treatments and results can be found in Khanal et al. [26], Tyagi and Lo [27] and Pilli et al. [28].

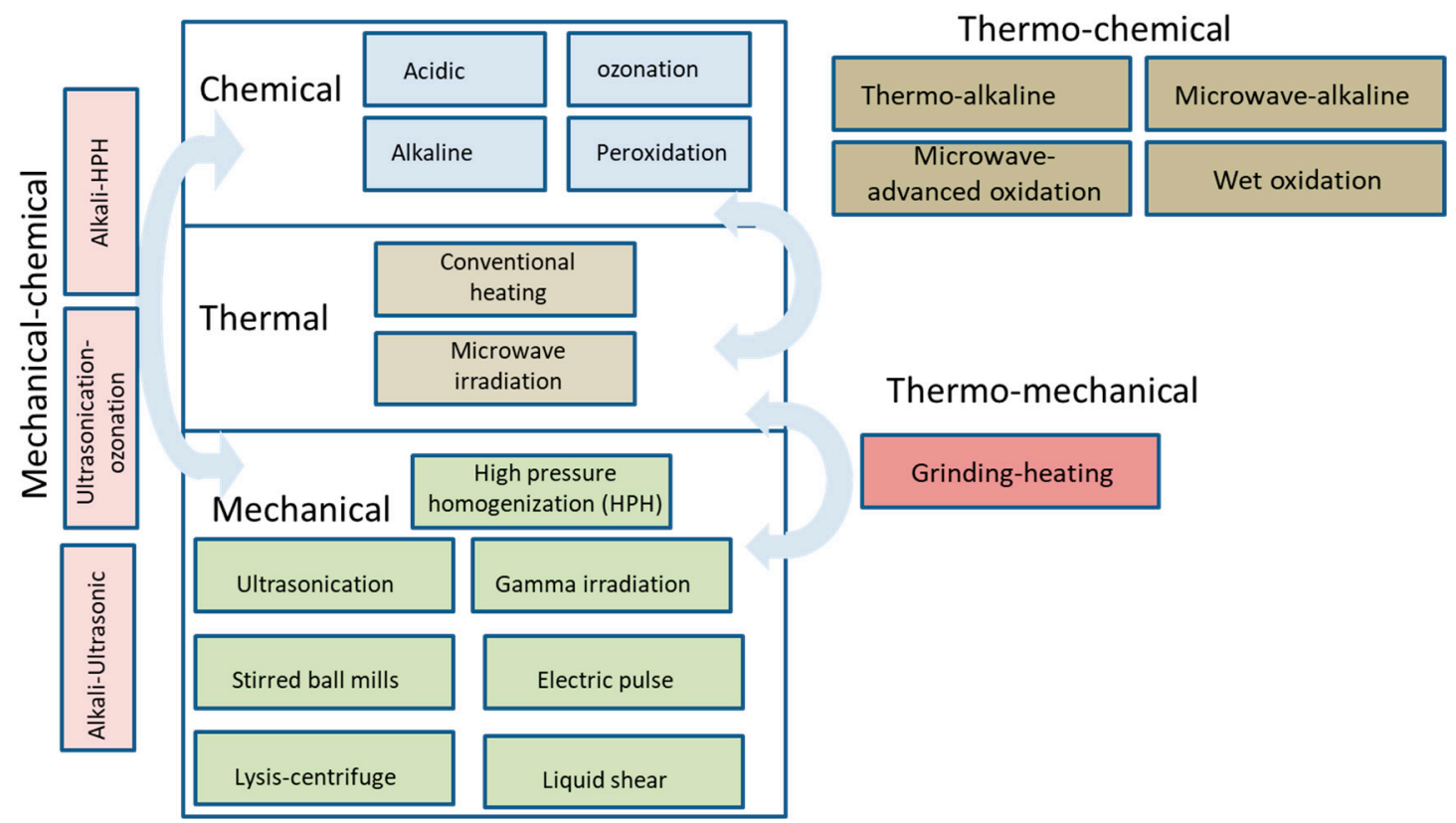

Figure 2. Classification of the different pre-treatment methods available for increasing substrate degradability and therefore the performance of the digestion process. Adapted from classification of pre-treatment processes of $[27,28]$.

Thermal pre-treatments have been extensively implemented at an industrial scale because they greatly increase the solubilisation of the organic matter [29] and offer the additional advantage of obtaining a stabilised sludge free of pathogens [30]. The internal recycling of heat allows for the recovery of energy inside the same process, which counterbalance its high energy demand for increasing the temperature to that of the thermal hydrolysis stage $\left(150-180^{\circ} \mathrm{C}\right)$. Other thermal processes, as it is microwave pre-treatments, have been proposed as a feasible technical alternative to attain a high degree of solubilisation and enhance the rate of degradation during anaerobic digestion with low energy demand [31]. Microwave irradiation can rapidly produce focused direct heat, which lowers energy losses during transmission. In addition, the changing dipole orientation of polar molecules that takes place causes "athermal" (non-thermal) effects which, when combined with thermal effects, greatly aids in denaturing complex biological molecules [32]. In spite of these advantages, the energy balance is not as favourable as in the traditional thermal pre-treatment due to the impossibility of recovering energy by recycling of heat, and also the fact that conventional thermal process is capable of accumulating heat for adjusting the high peak demand with the production stage; the latter is, however, not available for any other technology in which the energy demand is associated with the direct use of electricity [33]. 
The addition of bases or acids, to improve thermal degradation, has demonstrated to be a feasible option, particularly in the case of thermo-alkaline pre-treatments, which can improve biogas production up to a $54 \%$ when evaluating the digestion of waste activated sludge [34] and has proven to be the preferred choice when the pre-treatment is intended for attaining the delignification of biomass [35].

In general, mechanical methods present a lower enhancement in biogas production since the effect in the solubilisation of the organic material has a lower impact when compare with thermal pre-treatments. Advanced oxidation methods, on the contrary, are capable of attaining a great extent of disintegration of organic components, but its costs and energy demand (in the case of electrooxidation) makes this process a feasible alternative only for the cases where the presence of recalcitrant molecules is the main feature of the waste stream as it would be the case of complex industrial wastewaters [36,37]. Different types of electrodes have been tasted in an attempt to reduce the costs associated with this process and attain successful treatment of waste activated sludge [38].

Table 1 presents a list of different pre-treatments applied for improving anaerobic degradation of the organic matter. The studies of these different technologies have been widely applied to increase the digestibility of waste activated sludge (WAS). This organic material is generated in wastewater treatment plants as a result of the assimilation of the soluble compounds found in wastewaters by aerobic microorganisms. The excessive biomass growth in aerobic reactors favours a fast turnover of the organic compounds, but requires disposing the excess biomass as sludge. This sludge consists of a concentrated suspension of solids and biodegradable compounds [39]. In large scale wastewater treatment plants the traditional treatment of sludge is performed by anaerobic digestion. However, WAS has demonstrated to need high retention times in digesters and low degradability associated with the complex structure of their organic constituents. This brings, as result, the need for improving hydrolysis and acidification of this material in order to increase its degradation rate [40].

Table 1. Gas yields reported in literature regarding the effect of different pre-treatments on anaerobic digestion of waste activated sludge (WAS). Biogas or methane production data are reported either per unit of volatile solid (VS) or chemical oxygen demand (COD).

\begin{tabular}{cccc}
\hline Pre-Treatment & Biogas Yield & Improvement (\%) & Reference \\
\hline Ultrasound & $261 \mathrm{~mL} \mathrm{CH}_{4} / \mathrm{g} \mathrm{VS}$ & 30 & {$[24]$} \\
Thermal $\left(170^{\circ} \mathrm{C}\right)$ & $333 \mathrm{~mL} \mathrm{CH}_{4} / \mathrm{g} \mathrm{COD}$ & 50 & {$[41]$} \\
Ozonation & $259 \mathrm{~mL} \mathrm{CH}_{4} / \mathrm{g} \mathrm{COD}$ & 17 & {$[41]$} \\
Microwave & $183 \mathrm{~mL}$ biogas $/ \mathrm{Lr}^{1} \mathrm{~d}\left(\mathrm{HRT}^{2}=10 \mathrm{~d}\right)$ & 37 & {$[42]$} \\
Fenton & $547 \mathrm{~mL} \mathrm{CH} / \mathrm{g} \mathrm{VS}$ & 37 & {$[43]$} \\
Electro-oxidation $\left(\mathrm{Fe}\right.$ electrode- $\left.\mathrm{H}_{2} \mathrm{O}_{2}\right)$ & $147 \mathrm{~mL} \mathrm{biogas} / \mathrm{g} \mathrm{VS}$ & 256 & {$[44]$} \\
Electrochemical $\left(\mathrm{Ti} / \mathrm{RuO}_{2}\right)$ & $647 \mathrm{~mL} \mathrm{biogas} / \mathrm{g} \mathrm{VS}$ & 63.4 & {$[45]$} \\
Surfactant addition and mechanical disintegration & $180 \mathrm{~mL} \mathrm{CH}_{4} / \mathrm{g}$ VS & 260 & {$[46]$} \\
\hline
\end{tabular}

${ }^{1}$ Lr: reactor volume in liters, ${ }^{2}$ HRT: Hydraulic retention time.

The reduction of the energy demand of the different pre-treatment processes is a subject of on-going research. The effect on biogas enhancement and sludge minimisation must compensate for the high energy demand of pre-treatment methods. Recent research has been devoted to the evaluation of enzymatic hydrolysis and surfactant addition as a means for increasing digestibility [47]. However, the cost associated with this type of process represents a significant limitation. The use of fungal mash rich in hydrolytic enzymes was proposed by Yin and co-workers [48] as a way of reducing treatment costs. This seems a feasible approach, since these authors reported an improvement in methane production and a $54.3 \%$ reduction of biosolids when co-digesting sludge with food wastes.

Another way to improve performance of anaerobic digestion is by increasing the treatment efficiency through the addition of a co-substrate. Balancing nutrients is usually an approximation used for avoiding the accumulation of ammonia inside the digester which may cause a decrease in biogas production when inhibitory levels are reached. This is the reason for supplementing digesters treating manures with carbohydrate rich substrates. Co-digestion of swine manure, cattle and poultry manure have been studied for several years reporting better performance of the system when an organic material is added for increasing the organic loading of the reactors. The co-digestion of manures has 
led to numerous research works related with the evaluation of biogas yields using different types of co-substrates $[49,50]$.

Readily degradable materials, such as residual glycerine, cheese whey and food wastes, are added to digesters to increase biogas production rates [51-53]. However, the presence of these organic compounds can affect the fate of digestion; accumulation of VFAs may cause partial inhibitions which may finally affect the biogas yield [54]. Also, the presence of an abundant material which is easily converted by microorganisms may cause its preferential degradation causing a detriment in the stabilisation degree of the main residue. This is a relevant aspect which should not be overlooked. Anaerobic digestion is a process which is also focused on the treatment of wastes and on reducing their putrescible potential. However, when boosting biogas production, the degradation of rich carbohydrate materials is preferred by microorganisms over the degradation of more complex components such as proteins and lipids. Therefore, under the dynamic of fluids in continuously stirred tank reactors, the resulting digestate obtained at the hydraulic retention times typically applied in large scale digesters may need a post-stabilisation stage to further decrease its volatile solid content and its biological activity $[13,55]$.

The increase in VFA production when a readily biodegradable substrate is added to the digester can be seen as a new alternative for the valorisation of wastes. Although, the present application of anaerobic digestion is focus on energy production and waste stabilisation, the recovery of valuable compounds can be proposed as a new way for increasing revenues from the traditional digestion process. This is the case of the recovery of VFA by means of filtration membranes. The use of micro and nanofiltration membranes allows for the production of a stream free of particles and microorganism with a high content of acids [56]. In addition, the coupling of membranes for the treatment of digester liquid effluents allows not only for the recovery of green chemicals, but also facilitates the disposal of a liquid stream which is becoming increasingly expensive [57]. The conditions of the digestion can be easily optimised in the desired direction by changing hydraulic retention time or organic loading rate, therefore the dreaded VFA build-up in reactor operation can become a desired step if the aim of the digestion becomes obtaining green chemicals with multiples applications. VFA recovered from waste streams can be used for obtaining biodegradable polymers [polyhydroxyalkanoates (PHA), polyhydroxybutyrate (PHB), polylactate (PLA)], biodiesel (by means of fermenting processes), or either be used for increasing the treatment efficiency by coupling the digestion process with nutrient recovery systems, struvite recovery or for producing hydrogen [58-60].

Improving the performance of anaerobic digestion has been attempted by coupling different biological processes. The production of hydrogen can be performed by dark fermentation, which is usually coupled to anaerobic digestion as a first stage where hydrogen and short chain acids are produced [61,62]. The first fermentative stage usually operates at low hydraulic retention time which results in small reactors being needed and reduced installation costs. In addition, the capacity for using the whole substrate is limited in dark fermentation due to the high production of organic acids as by-products; thus, the application of this process as an intermediate stage becomes a reasonable option with the digestion process dedicated to the conversion of the hydrolysed material. The energy efficiency of the global process (coupling dark fermentation and anaerobic digestion) has been demonstrated to be increased by $13 \%$ when compared with the stand alone digestion configuration [63]. A similar approach has been also reported for integrating microbial electrolysis cells and anaerobic digestion, in this case for either increasing the efficiency of the organic matter degradation and thus methane production or increasing the production of energy by obtaining hydrogen [64,65]. In microbial electrolysis cells the oxidation of the organic matter is mediated by electrodes in an anodic chamber where a microbial biofilm catalysis this reaction. Hydrogen is produced in the cathode thanks to the application of small external voltage obtaining efficiencies of production higher than $90 \%$ [66]. The combined approximation allows for an oxidation of the organic material with the advantage of being operated under similar temperature conditions. Hydrogen can be directly used for energy production, or when handling this gas is not feasible due to incompatibility of the piping installation (because of the small 
volume of the hydrogen molecule), the direct injection of this gas in anaerobic digesters has been proposed for increasing methane production to up 30\% by favouring the action hydrogenotrophic methanoges $[67,68]$.

Other types of substrates such as cellulosic and lignocellulosic biomasses have also been studied as suitable co-substrates in anaerobic digestion to balance the carbon to nitrogen $(\mathrm{C}: \mathrm{N})$ ratio. The addition of cellulosic biomass as crop residues, grass and recently algae material has demonstrated to increase the methane production rate thanks to the increase attained in the organic load of the reactor, and no synergistic effect is clearly demonstrated from the co-digestion with manures. The addition of this material does not cause an increase in the specific methane production of the mixture compared with the biogas yields obtained for the individual substrates [69].

The use of lignocellulosic biomass is also another option, but in this case, several challenges need to be overcome, prior to consider it as a real alternative. The use of lignocellulosic biomass is hindered by the high energy demand associated with the pre-treatments needed to make accessible the cellulosic and hemicellulosic compounds to the anaerobic microflora [70]. In addition, based on the operating conditions of the reactor, some components as hemicellulose may be rapidly converted into methane, while living behind cellulose and lignin in the fibrous digested material [71]. One way of increasing the efficiency of the conversion process is by increasing the solid content of the organic material. Taking into account that the treatment of lignocellulosic biomass under anaerobic conditions will leave unconverted a fraction of the solid material, performing the process under a high solid configuration seems to be the most obvious way for attaining the digestion of this material. These high solid technologies (with solid content material greater than 15\%) are gaining great interest because of the advantage of the smaller size of the plant, but also lower heating energy demand, easiness of post-treatment of the digested material and lower liquid production [72,73]. The co-digestion of switchgrass with swine, poultry and dairy manure has shown promising results for the first one with methane yields similar to those obtained for submerged fermentation systems ( $337 \mathrm{~mL} \mathrm{CH}_{4} / \mathrm{g} \mathrm{VS}$ ) [72]. Although results for poultry manure are not as encouraging, the combination of co-digestion and high solid digestion technology may open a new feasible way for improving performance. This is the case of percolating systems for the co-digestion of poultry manure and sludge, where the single digestion of poultry manure may lead to poor results but the addition of the co-substrate exerted a positive influence by the increase in volatile solid destruction and biogas production [74].

Recent approaches for improving the performance of anaerobic reactors also include operation under high pressure. The reasoning behind this type of technology is associated with the need of up-grading biogas to be used as transport fuel. The behaviour of all systems under high pressure is governed by LeChâtelier's principle, which predicts that the application of pressure shifts equilibrium towards the state that occupies a smaller volume, and accelerates processes for which the transition state has a smaller volume than the ground state [75]. Therefore, it is highly expected that the microbial conversion of $\mathrm{CO}_{2}$ into $\mathrm{CH}_{4}$ would be favoured under high pressure conditions.

Recent research activities on high pressure anaerobic systems have demonstrated the feasibility of methanogenesis in a high-temperature petroleum reservoir. The incubations experiments were conducted by Mayumi and co-workers [76] without any substrate amendment and at $55{ }^{\circ} \mathrm{C}$ and $5 \mathrm{MPa}$. Results demonstrated the dominance of methane production by syntrophic acetate oxidation coupled to hydrogenotrophic methanogens in this environment. Considering the limits of life in terms of temperature $\left(122^{\circ} \mathrm{C}\right.$ for Methanopyrus kandlerii) and pressure (130-150 MPa for Pyrococcus yayanosii, thus occurring ca. $4 \mathrm{~km}$ below ground), the high pressure biotopes contribute significantly to the production and recycling of organic carbon on earth, representing about $50 \%$ of the primary biomass production [77-79]. Microorganisms isolated from these biotopes are often able to grow more efficiently under high hydrostatic pressure than under atmospheric pressure. These are referred to as piezophiles having optimal growth rates at pressures greater than $1 \mathrm{~atm}$ or $0.1 \mathrm{MPa}$. In addition, their inhibitory pressures are higher than those of surface organisms, often exceeding $100 \mathrm{MPa}$ [79]. These types of microbes belong to a wide variety of eubacterial and archaeal populations [80]. 
The feasibility of operating methanogenic reactors under high pressure condition has been demonstrated by Mayumi and co-workers [81]. These authors reported that the increase in $\mathrm{CO}_{2}$ pressure accelerates the rate of methanogenesis to more than twice. Isotope tracer and molecular analyses showed that high $\mathrm{CO}_{2}$ conditions invoke acetoclastic methanogenesis in place of syntrophic acetate oxidation coupled with hydrogenotrophic methanogenesis that typically occurs at low $\mathrm{CO}_{2}$ conditions. These findings would also explain why acetate is often the most abundant organic acid found in oil reservoirs.

On the other hand, Chen and co-workers [82] reported on the operation of anaerobic digestion at increasingly biogas pressure conditions inside the reactor (3-90 bar). This phenomenon led to an increase in the solubilisation of $\mathrm{CO}_{2}$ in the liquid phase which may have had a detrimental effect on the $\mathrm{pH}$ of the system but as additional advantage offered an enrichment of methane in biogas to values close to $90-95 \%$, lowering, based on the same reason, the content of other contaminants as $\mathrm{H}_{2} \mathrm{~S}$ and $\mathrm{NH}_{3}$ [83]. These preliminary investigations will presumably lead to the development of new technologies intended to increase the degradation rate of organic wastes and facilities that can overcome the present constraints associated with organic loading rates of digesters capable of attaining biogas up-grading at much lower costs.

\section{The Use of Carbon Conductive Materials for Improving Anaerobic Digestion}

The first demonstration of electrodes serving as a direct electron donor for anaerobic respiration was performed by Gregory et al. [84]. Their findings had great implications for the harvesting of electricity from anaerobic sediments and the bioremediation of oxidised contaminants. In previous reports, the capability of Geobacteraceae to growth attached to electrodes and use them as electron donors was reported by Bond et al. [85] and Tender et al. [86]. These authors used graphite electrodes as anodes and identified two anodes reactions: the first one was the oxidation of sediment sulfide (a by-product of microbial oxidation of sedimentary organic carbon) and the second one, the oxidation of sedimentary organic carbon catalysed by microorganisms colonising the anode.

Pure cultures within this family, such as Geobacter sulfurreducens, G. metallireducens and Desulfuromonas acetoxidans, have demonstrated the capability of supporting growth by oxidizing acetate or other organic compounds to carbon dioxide and transferring the electrons to the surface of a graphite electrode [85,87]. It is accepted that organisms other than Geobacteraceae may be also able to use electrodes as an electron acceptor without the need of requiring an exogenous electron shuttle. Summers and co-workers [20] introduced the concept of direct interspecies electron transfer (DIET) when evaluating the coculture of Geobacter metallireducens, an ethanol-oxidizing Fe(III) reducer, and Geobacter sulfurreducens. In their research, these authors tested the aforementioned organisms, because the latter one is incapable of metabolising ethanol, and was added to the culture to act as a hydrogen-consuming partner with the additional benefit that it can use fumarate as the electron acceptor, which cannot be used by G. metallireducens. The coupling of these two organisms led to the formation of an interesting aggregate being electrically conductive and suggested therefore the mechanism of DIET.

This mechanism has also been suggested to take place in anaerobic digesters. Morita and co-workers [21] proposed that microorganisms within some natural methanogenic aggregates may directly exchange electrons, instead of producing hydrogen or formate as an intermediary electron carrier. These authors evaluated the performance of an up-flow anaerobic sludge blanket reactor treating brewery waste to methane. This reactor contained aggregates with a low capacity for converting hydrogen into methane, and even though these aggregates were capable of converting formate into methane, the rate of conversion was too low to explain the high capacity of the reactor for assimilating ethanol. Aggregates in this type of experiment demonstrated that methanogenic species were electrically conductive and were predominantly enriched in anaerobic microorganisms most closely related to the acetate-utilizing Methanosaeta concilii. A similar suggestion was also reported by Rotaru et al. [88], who found that Methanosaeta species can make direct electrical connections with 
Geobacter species, accepting electrons for the reduction of carbon dioxide to methane. It seems that this collaboration within these two species is responsible for the recurrent finding of enhanced performance of anaerobic digesters when electrodes are introduced in anaerobic systems.

This statement was later corroborated by Zhao et al. [22], who reported that the introduction of graphite-brush anodes as electrodes in an anaerobic digester treating sewage sludge resulted in the predominance of Geobacter species being enriched in the digestion system. These species belonged to Geobacter metallireducens. The prevailing presence of Methanosaeta species in the microbial communities along with the presence of Geobacter species, capable of performing the direct exchange of electrons, was the reason for the "unknown" increase in methane production reported. Conductivity of the sludge in this electric-anaerobic digester was about $30 \%$ higher than that of the sludge in a control digester without electrodes.

On the other hand, the addition of Iron has a similar effect on anaerobic digestion, by increasing the production of methane and the reasoning behind this effect may keep a close relation with the improvement observed when carbon conductive material is supplemented. The addition of Iron (II) as a salt has been demonstrated to increase acetic conversion into methane [89], whereas the addition of zero valent iron $\left(\mathrm{Fe}^{0}\right)$ and iron scraps $(\mathrm{Fe}(\mathrm{III}))$ has been reported to increase the performance of the digestion of waste activated sludge. The addition of $\mathrm{Fe}^{0}$ favoured the presence of homoacetogens and hydrogenotrophic methanogens, while oxidized iron enhanced the diversity of acetobacteria and enriched iron-reducing bacteria $[90,91]$. Geobacter species are known to reduce iron oxides and their presence have been commonly reported in sediments and bioelectrochemical systems where their predominance is associated with its characteristic feature of using solid state compounds as electron acceptors $[92,93]$. Therefore, the enhancement in anaerobic digestion when carbon conductive materials are added to a conventional digester seems to be associated with the bio-augmentation of anaerobic species capable of providing a different route for electron transport as it is the collaboration between methanogens and Geobacter species [94].

Different carbon conductive materials have been evaluated in the digestion of complex wastes. Results reported by several authors when allowing the presence of an external material to serve as electrons transport have led to open an innovative path for improving anaerobic digestion. The performance of digestion is reportedly improved when taking advantage of this feature. In particular, the use of carbon based materials, as it is carbon cloth, carbon felt and granular activated carbon has proven to enhance the treatment of high organic loading streams and favour the recovery of sour reactors [95].

The use of activated carbon along with different types of adsorbents has demonstrated to enhance the performance of digestion. Desai and Madamwar [96] studied the addition of silica gel, bentonite, among others, to evaluate the effect of methane production when digesting manures and cheese whey. Their results (about two-fold enhancement) were also in agreement with those previously reported by Patel et al. [97], studying the addition of different types of adsorbents in the digestion cattle dung. This initial line of research has led to extensive studies on the use of activated carbon and consequently, because of the imperative need of reducing treatment cost, the use of biochar.

There exist numerous reports on the performance of reactors operating with the use of different adsorbents. Adsorbents can be defined as chemically inert materials with properties that allow the accumulation of atoms, ions or molecules on their surface. This is a surface based interaction between a solid and a fluid with the rate of sorption being dependent on the adsorbent (the material used as the adsorbing phase) and the adsorbate (the material being adsorbed) [98]. Therefore, the implication of these materials in the microbial degradation of wastes has been traditionally associated with their capacity of removing toxic compounds from the culture lowering the inhibitory burden microorganisms need to overcome.

Zeolites have been traditionally studied in digestions systems to enhance the performance of reactors with high nitrogen levels thanks to its natural capacity to exchange cations $\left(\mathrm{Ca}^{2+}\right.$ and $\left.\mathrm{Mg}^{2+}\right)$ and remove ammonium [99-101]. The use of bentonite was tested by Angelidaki and co-workers [102] 
for reducing the inhibitory effect of long chain fatty acids. The performance of reactors is reported to be significantly improved but the cost of using adsorbents seems to set an important burden to the process.

Similarly, the benefits in the use of activated carbon have also been explained by its adsorption capacity of inhibitory compounds [103]. However, recent reports demonstrated that its ability for improving digestion performance should be explained based on a combination of different factors. This statement was demonstrated by Cuetos and co-workers [104] who studied the digestion of poultry blood. This waste stream is an organic material of difficult degradation due to its high carbon and protein content which leads to a rapid accumulation of VFAs and ammonium under anaerobic conditions, causing a complete inhibition of the process. The addition of granular activated carbon to the digestion of blood as sole substrate resulted in a better assimilation of $C_{3}-C_{5}$ acid forms, indicating that an enhancement in syntrophic metabolism may have taken place. The addition of granular activated carbon (GAC) may favour the adsorption of ammonium, offering protection to the microbial biomass by limiting mass transfer of toxic compounds, and also acting as a conductive material. These features may explain the successful digestion of residual blood as the sole substrate obtained by Cuetos et al. [105].

The addition of GAC has also been studied in digesters treating food wastes, where the presence of this carbon material favoured the growth of archaea and syntrophic bacteria, suggesting that interactions between these microorganisms were enhanced with the predominance of hydrogenotrophic methanogens [106]. The combination of factors, as it is the transport of electrons and the important role of this material associated with the removal of inhibitory compounds by adsorption phenomena has led to the extensive search for alternative materials with similar qualities.

Anaerobic reactors treating complex wastes may be often submitted to stress conditions as it is high concentration of inhibitory compounds and acid intermediaries. These are common features frequently found in industrial scale reactors, hence developing strategies for the rapid recovery of these systems seems crucial in order to prevent the complete failure of the process. With this aim, the behaviour of anaerobic microbial systems was evaluated using carbon felt electrodes as supporting material when the digestion was forced to inhibitory acid conditions by organic overloading. The mere presence of the electrodes delayed the accumulation of volatile fatty acids, being indicative of the effect this type of materials has on the enhancement on the metabolism of VFA [107]. The performance of combined digestion and microbial electrolysis systems was previously studied by De Vrieze et al. [108]. These authors evaluated the digestion of molasses and indicated a stabilising effect on the process when bioelectrochemical systems are coupled to the reactor. However, the reported benefit was explained on the capacity of electrodes for retaining anaerobic microflora rather than an effect associated with the application of a cell potential.

Following this same line of research, the introduction of bioelectochemical systems to anaerobic reactors was proposed as an alternative capable of integrating two anaerobic microbial processes which could benefit from the presence of electrodes and mediate in the conversion of organic materials. This combined reactor was tested in the stabilisation of waste activated sludge reporting a significant improvement in the rate of methane production (up to 3 times compared to the digestion stand-alone configuration) [109]. These results were also in agreement with those published by Feng and co-workers [110], studying this same organic substrate in a similar configuration of microbial electrolysis cell reactor and anaerobic digestion. In this later work high solid content was a differentiating feature. Results obtained under these conditions proved the superior performance of the combined approach by reporting a $22.4 \%$ increase in methane production when iron-graphite electrodes were used. More impressive results were described for the use of a single chamber reactor also integrating both processes and carbon felt electrodes. Methane content in excess of $98 \%$ was achieved from the microbial electrolysis cell and anaerobic digestion coupled process. An increase in methane yield of 2.3 times was also obtained being explained by the in situ conversion of $\mathrm{CO}_{2}$ into methane on the anode by hydrogenotrophic electromethanogens (e.g., Methanospirillum), which were 
the dominant population. These microbes could utilize hydrogen gas generated at the inner surface of stainless steel reactor, which also served as cathode of the microbial electrolysis cell [111].

However, the success of the different reactor configurations and alternatives for improving digestion performance are intimately linked to the installation and operating costs. Searching for techniques capable of producing low-cost adsorbents or low-cost microbial electrolysis systems have become a wide field of research. Lignocelullosic biomass, agricultural by-products and wastes have traditionally served as cheap raw materials for the production of energy from biomass and for the recovery of low-cost adsorbents [112-114].

Biochar is a carbon-rich by-product resulting from the burning of biomasses at high temperatures $\left(300-1000{ }^{\circ} \mathrm{C}\right.$ ) either under low levels of oxygen (gasification) or under its complete absence (pyrolysis) [115]. This material is known to present adsorption properties and special features as soil amendments having positive effects on plant growth, associated with the capacity of retaining soil nutrients, increasing soil-water retention capacity and enhancing cation exchange capacity [116,117]. Different feedstocks serve as raw materials for obtaining biochar, as it is; organic wastes derived from agriculture and forestry, or urban wastes including sewage sludge [118]. However, its properties are greatly dependent on the feedstock used and the process conditions (temperature, atmosphere and heating rate) $[119,120]$.

For several years the effect of biochar in soils has been studied, reporting different benefits which may be associated with its chemical and physical characteristics. Only in recent years have researchers focused their attention on extrapolating its use to anaerobic digestion systems, considering its capacity of acting as a low-cost adsorbent of inhibitory compounds and reporting relevant results regarding the improvement obtained in the performance of the digestion which could not be explained just by the removal of toxic compounds [105]. Table 2 presents a list of different experiences regarding the effect of supplementing anaerobic digestion systems with biochar. Improvements in the rate of degradation and increase in methane yields have been reported by several authors [121-123]. Addition of biochar to anaerobic digestion systems is suggested to reduce inhibitory stages and favours stability of the process thanks to its capacity for adsorbing toxic compounds, increasing buffering capacity and aiding in the immobilisation of anaerobic microflora [98].

Table 2. Results obtained from biochar supplemented reactor when evaluating the effect on biogas yields.

\begin{tabular}{|c|c|c|c|}
\hline Source of Biochar & Substrate & Main Results & Reference \\
\hline Fruitwood & Glucose $(4-8 \mathrm{~g} / \mathrm{L})$ & $\begin{array}{l}\text { Biochar shortened the methanogenic lag phase and increased } \\
\text { maximum methane production rate in } 86.6 \% \text { at } 4 \mathrm{~g} / \mathrm{L} \text { of glucose } \\
\text { concentration and just } 5.2 \% \text { at the highest glucose concentration }(8 \mathrm{~g} / \mathrm{L})\end{array}$ & [121] \\
\hline Fruitwood & $\begin{array}{l}\text { Food wastes (4-10 g Dry } \\
\text { Weight/L) }\end{array}$ & $\begin{array}{l}\text { Biochar shortened the methanogenic lag phase and increased } \\
\text { maximum methane production rate by } 123 \%\end{array}$ & [122] \\
\hline Almond shell & Swine manure & $\begin{array}{l}\text { Increased in methane yield of } 39 \% \text {. Addition of biochar enhanced the } \\
\text { degradation of proteins }\end{array}$ & [123] \\
\hline Fruitwood & Glucose N: 0.26-7 g/L & $\begin{array}{l}\text { Biochar accelerated the initiation of mechanisation during anaerobic } \\
\text { digestion under double inhibition risk from both ammonium and acids. } \\
\text { Increased maximum methane production rate by } 38 \%\end{array}$ & [124] \\
\hline Corn Stover & Sewage sludge & $\begin{array}{l}\text { Biochar-amended digesters produced near pipeline-quality biomethane } \\
\left(>90 \% \mathrm{CH}_{4} \text { and }<5 \mathrm{ppb} \mathrm{H}_{2} \mathrm{~S}\right) \text {. The biochar addition also increased } \\
\text { alkalinity and mitigated ammonia inhibition. Increased maximum } \\
\text { methane production rate by } 27.6 \%\end{array}$ & [125] \\
\hline $\begin{array}{l}\text { Clean forestry } \\
\text { wood residue } \\
\text { (Holm Oak) }\end{array}$ & $\begin{array}{c}\text { Organic fraction of } \\
\text { municipal solid waste } \\
\text { (solid state fermentation) }\end{array}$ & Methane yield increased around 5\% with biochar addition & [126] \\
\hline Vineyard pruning & Orange peels & $\begin{array}{l}\text { Increased in methane yield of } 56 \% \text {. Biochar addition favoured the } \\
\text { electro-active microorganisms consortia creating a synthrophic } \\
\text { metabolism between eubacterial and archaeal populations }\end{array}$ & [127] \\
\hline $\begin{array}{l}\text { Wheat bran } \\
\text { pellets, coppiced } \\
\text { woodlands, and } \\
\text { orchard pruning }\end{array}$ & $\begin{array}{l}\text { Food waste fermentate } \\
\text { from acidogenic reactor }\end{array}$ & $\begin{array}{l}\text { Conversion of VFAs proceeded at a rate up to } 5 \text { times higher than that } \\
\text { observed in the unamended controls. Biochar affected the composition } \\
\text { of the microbial consortium. Positive effect observed was directly } \\
\text { related to the electron-donating capacity (EDC) of the material, but was } \\
\text { independent of its bulk electrical conductivity and specific surface area }\end{array}$ & [128] \\
\hline
\end{tabular}


The enhancement obtained in anaerobic digestion with the supplementation of biochar leads to considering as reasonable the coupling of pyrolysis and digestion technologies for the global treatment of waste organic material. This combined approached has been studied by Monlau and co-workers [129] and Hübner and Mumme [130] either by considering the production of biochar from anaerobic digestate or by the degradation of the aqueous phase of pyrolysis liquor in the anaerobic digester. The approach seems promising and this is particularly true if the enhancement in the global efficiency of the combined approach is considered.

Figure 3 is a schematic representation of the different possibilities available for an integrated management of waste organic material considering anaerobic digestion and pyrolysis. Salman and co-workers [131] evaluated a simulation of the combined approach integrated into a bio refinery concept to establish the benefits obtained from the energy and exergy point of view. These authors reported a global efficiency of $59 \%$ for the combined configuration against a $52 \%$ for the anaerobic digestion stand-alone process. Hence, the use of biochar as supplement in the digestion process has led to consider as a feasible option the full integration of biological and thermal valorisation of organic wastes bringing out as additional benefit the significantly reduction in the amount of material needing final disposal.

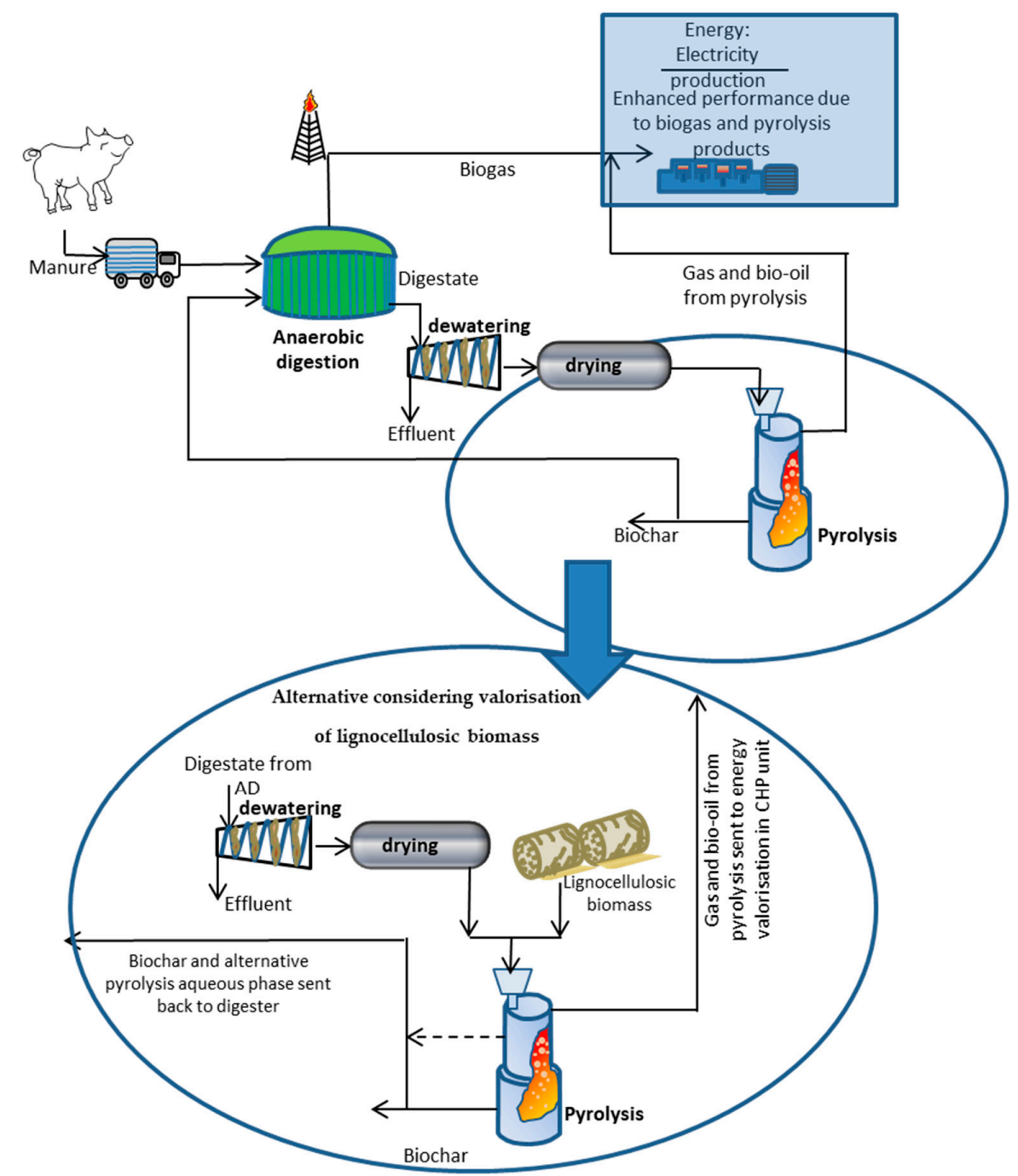

Figure 3. Schematic representation of the valorisation of waste and lignocellulosic biomass for energy production. The configuration considers the integration of anaerobic digestion and pyrolysis for the treatment of swine manure. Biochar produced by pyrolysis is used as supplement in the digestion process. Digestion of the aqueous phase is proposed also as alternative. 


\section{Conclusions}

Anaerobic digestion is a well-known technology presenting a wide application in the treatment of high loaded organic effluents and in the valorisation of biomass into biogas. The enhancement of biogas yields of organic substrates mostly keep relation with the increase in the degradation rate. This can be performed by the application of different types of pre-treatment to the organic compounds, but this implies a high energy demand. This review also presents the effects reported on by different research works when evaluating the performance of the digestion process supplemented by carbon conductive materials, with the main focus on the use of biochar. The use of carbon conductive materials aids in the degradation rate of substrate by allowing an alternative route for electron transport. The use of biochar and recently hydrochar seems to be a feasible way for increasing the performance of anaerobic digesters and opens a new approach for the global valorisation of organic wastes by the integration of anaerobic digestion and thermal processes. This combined configuration allows for increasing the efficiency of the whole treatment process and greatly reduces the amount of material needing final disposal.

Author Contributions: Individual contributions of the authors is the following: conceptualization, X.G. and M.E.S.; resources, X.G.; data curation, J.G.; writing—original draft preparation, X.G. and J.G.; writing-review and editing, X.G.; visualization, M.E.S. and J.G.; supervision, X.G. and M.E.S.; project administration, X.G.; funding acquisition, X.G.

Funding: This research was funded by Ministerio de Economía y Competitividad and Fondo Europeo de Desarrollo Regional through the project ref: CTQ2015-68925-R and UNLE15-EE-3070.

Conflicts of Interest: The authors declare no conflict of interest.

\section{References}

1. Manyi-Loh, C.E.; Mamphweli, S.N.; Meyer, E.L.; Okoh, A.I.; Makaka, G.; Simon, M. Microbial anaerobic digestion (bio-digesters) as an approach to the decontamination of animal wastes in pollution control and the generation of renewable energy. Int. J. Environ. Res. Public Health 2013, 10, 4390-4417. [CrossRef] [PubMed]

2. Tsai, W.T. Regulatory Promotion and Benefit Analysis of Biogas-Power and Biogas-Digestate from Anaerobic Digestion in Taiwan's Livestock Industry. Fermentation 2018, 4, 57. [CrossRef]

3. Spinosa, L.; Ayol, A.; Baudez, J.C.; Canziani, R.; Jenicek, P.; Leonard, A.; Rulkens, W.; Xu, G.; Van Dijk, L. Sustainable and innovative solutions for sewage sludge management. Water 2011, 3, 702-717. [CrossRef]

4. Cao, Y.; Pawłowski, A. Sewage sludge-to-energy approaches based on anaerobic digestion and pyrolysis: Brief overview and energy efficiency assessment. Renew. Sustain Energy Rev. 2012, 16, 1657-1665. [CrossRef]

5. Pastor-Bueis, R.; Mulas, R.; Gómez, X.; González-Andrés, F. Innovative liquid formulation of digestates for producing a biofertilizer based on Bacillus siamensis: Field testing on sweet pepper. J. Plant Nutr. Soil Sci. 2017, 180, 748-758. [CrossRef]

6. Vavilin, V.A.; Fernandez, B.; Palatsi, J.; Flotats, X. Hydrolysis kinetics in anaerobic degradation of particulate organic material: An overview. Waste Manag. 2008, 28, 939-951. [CrossRef] [PubMed]

7. Franke-Whittle, I.H.; Walter, A.; Ebner, C.; Insam, H. Investigation into the effect of high concentrations of volatile fatty acids in anaerobic digestion on methanogenic communities. Waste Manag. 2014, 34, 2080-2089. [CrossRef] [PubMed]

8. Ahring, B.K.; Sandberg, M.; Angelidaki, I. Volatile fatty acids as indicators of process imbalance in anaerobic digestors. Appl. Microbiol. Biotechnol. 1995, 43, 559-565. [CrossRef]

9. Angelidaki, I.; Ellegaard, L.; Ahring, B.K. A mathematical model for dynamic simulation of anaerobic digestion of complex substrates: Focusing on ammonia inhibition. Biotechnol. Bioeng. 1993, 42, 159-166. [CrossRef] [PubMed]

10. Siegert, I.; Banks, C. The effect of volatile fatty acid additions on the anaerobic digestion of cellulose and glucose in batch reactors. Process Biochem. 2005, 40, 3412-3418. [CrossRef]

11. Wang, Y.; Zhang, Y.; Wang, J.; Meng, L. Effects of volatile fatty acid concentrations on methane yield and methanogenic bacteria. Biomass Bioenerg. 2009, 33, 848-853. [CrossRef] 
12. Pullammanappallil, P.C.; Chynoweth, D.P.; Lyberatos, G.; Svoronos, S.A. Stable performance of anaerobic digestion in the presence of a high concentration of propionic acid. Bioresour. Technol. 2001, 78, 165-169. [CrossRef]

13. Fierro, J.; Martinez, E.J.; Rosas, J.G.; Fernández, R.A.; López, R.; Gomez, X. Co-Digestion of swine manure and crude glycerine: Increasing glycerine ratio results in preferential degradation of labile compounds. Water Air Soil Pollut. 2016. [CrossRef]

14. Fountoulakis, M.S.; Petousi, I.; Manios, T. Co-digestion of sewage sludge with glycerol to boost biogas production. Waste Manag. 2010, 30, 1849-1853. [CrossRef] [PubMed]

15. Angelidaki, I.; Batstone, D.J. Anaerobic digestion: Process. Solid Waste Technol. Manag. 2010. [CrossRef]

16. Demirel, B.; Scherer, P. The roles of acetotrophic and hydrogenotrophic methanogens during anaerobic conversion of biomass to methane: A review. Rev. Environ. Sci. Bio/Technol. 2008, 7, 173-190. [CrossRef]

17. Liu, Y.; Whitman, W.B. Metabolic, phylogenetic, and ecological diversity of the methanogenic archaea. Ann. N. Y. Acad. Sci. 2008, 1125, 171-189. [CrossRef] [PubMed]

18. Smith, K.S.; Ingram-Smith, C. Methanosaeta, the forgotten methanogen? Trends Microbiol. 2007, 15, $150-155$. [CrossRef] [PubMed]

19. Stams, A.J.M.; Plugge, C.M. Electron transfer in syntrophic communities of anaerobic bacteria and archaea. Nat. Rev. Microbiol. 2009. [CrossRef] [PubMed]

20. Summers, Z.M.; Fogarty, H.E.; Leang, C.; Franks, A.E.; Malvankar, N.S.; Lovley, D.R. Direct exchange of electrons within aggregates of an evolved syntrophic coculture of anaerobic bacteria. Science 2010, 330, 1413-1415. [CrossRef] [PubMed]

21. Morita, M.; Malvankar, N.S.; Franks, A.E.; Summers, Z.M.; Giloteaux, L.; Rotaru, A.E.; Rotaru, C.; Lovley, D.R. Potential for direct interspecies electron transfer in methanogenic wastewater digester aggregates. $m B i o$ 2011, 2, e00159-11. [CrossRef] [PubMed]

22. Zhao, Z.; Zhang, Y.; Wang, L.; Quan, X. Potential for direct interspecies electron transfer in an electric-anaerobic system to increase methane production from sludge digestion. Sci. Rep. 2015, 5, 11094. [CrossRef] [PubMed]

23. Bonmati, A.; Flotats, X.; Mateu, L.; Campos, E. Study of thermal hydrolysis as a pretreatment to mesophilic anaerobic digestion of pig slurry. Water Sci. Technol. 2001, 44, 109-116. [CrossRef] [PubMed]

24. Martínez, E.J.; Rosas, J.G.; Morán, A.; Gómez, X. Effect of ultrasound pretreatment on sludge digestion and dewatering characteristics: Application of particle size analysis. Water 2015, 7, 6483-6495. [CrossRef]

25. Sträuber, H.; Bühligen, F.; Kleinsteuber, S.; Nikolausz, M.; Porsch, K. Improved anaerobic fermentation of wheat straw by alkaline pre-treatment and addition of alkali-tolerant microorganisms. Bioengineering 2015, 2, 66-93. [CrossRef] [PubMed]

26. Khanal, S.K.; Grewell, D.; Sung, S.; Van Leeuwen, J. Ultrasound applications in wastewater sludge pretreatment: A review. Crit. Rev. Environ. Sci. Technol. 2007, 37, 277-313. [CrossRef]

27. Tyagi, V.K.; Lo, S.L. Application of physico-chemical pretreatment methods to enhance the sludge disintegration and subsequent anaerobic digestion: An up to date review. Rev. Environ. Sci. Bio/Technol. 2011, 10, 215. [CrossRef]

28. Pilli, S.; Yan, S.; Tyagi, R.D.; Surampalli, R.Y. Thermal pretreatment of sewage sludge to enhance anaerobic digestion: A review. Crit. Rev. Environ. Sci. Technol. 2015, 45, 669-702. [CrossRef]

29. Carrère, H.; Dumas, C.; Battimelli, A.; Batstone, D.J.; Delgenès, J.P.; Steyer, J.P.; Ferrer, I. Pretreatment methods to improve sludge anaerobic degradability: A review. J. Hazard. Mater. 2010. [CrossRef] [PubMed]

30. Kepp, U.; Machenbach, I.; Weisz, N.; Solheim, O.E. Enhanced stabilisation of sewage sludge through thermal hydrolysis-three years of experience with full scale plant. Water Sci. Technol. 2000, 42, 89-96. [CrossRef]

31. Martínez, E.J.; Gil, M.V.; Rosas, J.G.; Moreno, R.; Mateos, R.; Morán, A.; Gómez, X. Application of thermal analysis for evaluating the digestion of microwave pre-treated sewage sludge. J. Therm. Anal. Calorim. 2017, 127, 1209-1219. [CrossRef]

32. Chi, Y.; Li, Y.; Fei, X.; Wang, S.; Yuan, H. Enhancement of thermophilic anaerobic digestion of thickened waste activated sludge by combined microwave and alkaline pretreatment. J. Environ. Sci. 2011, 23, 1257-1265. [CrossRef]

33. García-Cascallana, J.; Borge-Díez, D.; Gómez, X. Enhancing the efficiency of thermal hydrolysis process in wastewater treatment plants by the use of steam accumulation. Int. J. Environ. Sci. Technol. 2018. [CrossRef] 
34. Valo, A.; Carrere, H.; Delgenes, J.P. Thermal, chemical and thermo-chemical pre-treatment of waste activated sludge for anaerobic digestion. J. Chem. Technol. Biotechnol. 2004, 79, 1197-1203. [CrossRef]

35. Sattar, A.; Arslan, C.; Ji, C.; Sattar, S.; Ali Mari, I.; Rashid, H.; Ilyas, F. Comparing the bio-hydrogen production potential of pretreated rice straw co-digested with seeded sludge using an anaerobic bioreactor under mesophilic thermophilic conditions. Energies 2016, 9, 198. [CrossRef]

36. Wang, C.; Zhang, M.; Liu, W.; Ye, M.; Su, F. Effluent characteristics of advanced treatment for biotreated coking wastewater by electrochemical technology using BDD anodes. Environ. Sci. Pollut. Res. 2015, 22, 6827-6834. [CrossRef] [PubMed]

37. Martinez, E.J.; Rosas, J.G.; Gonzalez, R.; Garcia, D.; Gomez, X. Treatment of vinasse by electrochemical oxidation: Evaluating the performance of boron-doped diamond (BDD)-based and dimensionally stable anodes (DSAs). Int. J. Environ. Sci. Technol. 2018, 15, 1159-1168. [CrossRef]

38. Curteanu, S.; Godini, K.; Piuleac, C.G.; Azarian, G.; Rahmani, A.R.; Butnariu, C. Electro-oxidation method applied for activated sludge treatment: Experiment and simulation based on supervised machine learning methods. Ind. Eng. Chem. Res. 2014, 53, 4902-4912. [CrossRef]

39. Rizzardini, C.B.; Goi, D. Sustainability of domestic sewage sludge disposal. Sustainability 2014, 6, $2424-2434$. [CrossRef]

40. Zhang, D.; Chen, Y.; Zhao, Y.; Zhu, X. New sludge pretreatment method to improve methane production in waste activated sludge digestion. Environ. Sci. Technol. 2010, 44, 4802-4808. [CrossRef] [PubMed]

41. Bougrier, C.; Albasi, C.; Delgenès, J.P.; Carrère, H. Effect of ultrasonic, thermal and ozone pre-treatments on waste activated sludge solubilisation and anaerobic biodegradability. Chem. Eng. Process. Process Intensif. 2006, 45, 711-718. [CrossRef]

42. Park, B.; Ahn, J.H.; Kim, J.; Hwang, S. Use of microwave pretreatment for enhanced anaerobiosis of secondary sludge. Water Sci. Technol. 2004, 50, 17-23. [CrossRef] [PubMed]

43. Erden, G.; Filibeli, A. Improving anaerobic biodegradability of biological sludges by Fenton pre-treatment: Effects on single stage and two-stage anaerobic digestion. Desalination 2010, 251, 58-63. [CrossRef]

44. Feki, E.; Khoufi, S.; Loukil, S.; Sayadi, S. Improvement of anaerobic digestion of waste-activated sludge by using $\mathrm{H}_{2} \mathrm{O}_{2}$ oxidation, electrolysis, electro-oxidation and thermo-alkaline pretreatments. Environ. Sci. Pollut. Res. 2015, 22, 14717-14726. [CrossRef] [PubMed]

45. Yu, B.; Xu, J.; Yuan, H.; Lou, Z.; Lin, J.; Zhu, N. Enhancement of anaerobic digestion of waste activated sludge by electrochemical pretreatment. Fuel 2014, 130, 279-285. [CrossRef]

46. Kavitha, S.; Pray, S.S.; Yogalakshmi, K.N.; Kumar, S.A.; Yeom, I.T. Effect of chemo-mechanical disintegration on sludge anaerobic digestion for enhanced biogas production. Environ. Sci. Pollut. Res. 2016, 23, 2402-2414. [CrossRef] [PubMed]

47. Kavitha, S.; Jayashree, C.; Kumar, S.A.; Yeom, I.T.; Banu, J.R. The enhancement of anaerobic biodegradability of waste activated sludge by surfactant mediated biological pretreatment. Bioresour. Technol. 2014, 168, 159-166. [CrossRef] [PubMed]

48. Yin, Y.; Liu, Y.J.; Meng, S.J.; Kiran, E.U.; Liu, Y. Enzymatic pretreatment of activated sludge, food waste and their mixture for enhanced bioenergy recovery and waste volume reduction via anaerobic digestion. Appl. Energy 2016, 179, 1131-1137. [CrossRef]

49. Al bkoor Alrawashdeh, K.; Pugliese, A.; Slopiecka, K.; Pistolesi, V.; Massoli, S.; Bartocci, P.; Bidini, G.; Fantozzi, F. Codigestion of untreated and treated sewage sludge with the organic fraction of municipal solid wastes. Fermentation 2017, 3, 35. [CrossRef]

50. Prapinagsorn, W.; Sittijunda, S.; Reungsang, A. Co-Digestion of Napier Grass and Its Silage with Cow Dung for Methane Production. Energies 2017, 10, 1654. [CrossRef]

51. Gelegenis, J.; Georgakakis, D.; Angelidaki, I.; Mavris, V. Optimization of biogas production by co-digesting whey with diluted poultry manure. Renew. Energy 2007, 32, 2147-2160. [CrossRef]

52. Li, R.; Chen, S.; Li, X. Biogas production from anaerobic co-digestion of food waste with dairy manure in a two-phase digestion system. Appl. Biochem. Biotechnol. 2010, 160, 643-654. [CrossRef] [PubMed]

53. Marañón, E.; Castrillón, L.; Quiroga, G.; Fernández-Nava, Y.; Gómez, L.; García, M.M. Co-digestion of cattle manure with food waste and sludge to increase biogas production. Waste Manag. 2012, 32, 1821-1825. [CrossRef] [PubMed]

54. Fernández, C.; Blanco, D.; Fierro, J.; Martínez, E.J.; Gómez, X. Anaerobic co-digestion of sewage sludge with cheese whey under thermophilic and mesophilic conditions. Int. J. Energy Eng. 2014, 4, 26-31. [CrossRef] 
55. González, R.; Smith, R.; Blanco, D.; Fierro, J.; Gómez, X. Application of thermal analysis for evaluating the effect of glycerine addition on the digestion of swine manure. J. Therm. Anal. Calorim. 2018. [CrossRef]

56. Zacharof, M.P.; Lovitt, R.W. Recovery of volatile fatty acids (VFA) from complex waste effluents using membranes. Water Sci. Technol. 2014, 69, 495-503. [CrossRef] [PubMed]

57. Zacharof, M.P.; Mandale, S.J.; Williams, P.M.; Lovitt, R.W. Nanofiltration of treated digested agricultural wastewater for recovery of carboxylic acids. J. Clean. Prod. 2016, 112, 4749-4761. [CrossRef]

58. Zacharof, M.P.; Lovitt, R.W. Complex effluent streams as a potential source of volatile fatty acids. Waste Biomass Valoriz. 2013, 4, 557-581. [CrossRef]

59. Lee, W.S.; Chua, A.S.M.; Yeoh, H.K.; Ngoh, G.C. A review of the production and applications of waste-derived volatile fatty acids. Chem. Eng. J. 2014, 235, 83-99. [CrossRef]

60. Piveteau, S.; Picard, S.; Dabert, P.; Daumer, M.L. Dissolution of particulate phosphorus in pig slurry through biological acidification: A critical step for maximum phosphorus recovery as struvite. Water Res. 2017, 124, 693-701. [CrossRef] [PubMed]

61. Cuetos, M.J.; Gomez, X.; Escapa, A.; Moran, A. Evaluation and simultaneous optimization of bio-hydrogen production using 32 factorial design and the desirability function. J. Power Sources 2007, 169, 131-139. [CrossRef]

62. Akinbomi, J.; Wikandari, R.; Taherzadeh, M.J. Enhanced fermentative hydrogen and methane production from an inhibitory fruit-flavored medium with membrane-encapsulated cells. Membranes 2015, 5, 616-631. [CrossRef] [PubMed]

63. Massanet-Nicolau, J.; Dinsdale, R.; Guwy, A.; Shipley, G. Utilising biohydrogen to increase methane production, energy yields and process efficiency via two stage anaerobic digestion of grass. Bioresour. Technol. 2015, 189, 379-383. [CrossRef] [PubMed]

64. Cai, W.; Liu, W.; Yang, C.; Wang, L.; Liang, B.; Thangavel, S.; Guo, Z.; Wang, A. Biocathodic methanogenic community in an integrated anaerobic digestion and microbial electrolysis system for enhancement of methane production from waste sludge. ACS Sustain. Chem. Eng. 2016, 4, 4913-4921. [CrossRef]

65. Liu, W.; He, Z.; Yang, C.; Zhou, A.; Guo, Z.; Liang, B.; Varrone, C.; Wang, A.J. Microbial network for waste activated sludge cascade utilization in an integrated system of microbial electrolysis and anaerobic fermentation. Biotechnol. Biofuels 2016. [CrossRef] [PubMed]

66. Chandrasekhar, K.; Lee, Y.J.; Lee, D.W. Biohydrogen production: Strategies to improve process efficiency through microbial routes. Int. J. Mol. Sci. 2015, 16, 8266-8293. [CrossRef] [PubMed]

67. Luo, G.; Angelidaki, I. Co-digestion of manure and whey for in situ biogas upgrading by the addition of $\mathrm{H}_{2}$ : Process performance and microbial insights. Appl. Microbiol. Biotechnol. 2013, 97, 1373-1381. [CrossRef] [PubMed]

68. Luo, G.; Johansson, S.; Boe, K.; Xie, L.; Zhou, Q.; Angelidaki, I. Simultaneous hydrogen utilization and in situ biogas upgrading in an anaerobic reactor. Biotechnol. Bioeng. 2012, 109, 1088-1094. [CrossRef] [PubMed]

69. Cuetos, M.J.; Fernández, C.; Gómez, X.; Morán, A. Anaerobic co-digestion of swine manure with energy crop residues. Biotechnol. Bioprocess Eng. 2011. [CrossRef]

70. Sawatdeenarunat, C.; Surendra, K.C.; Takara, D.; Oechsner, H.; Khanal, S.K. Anaerobic digestion of lignocellulosic biomass: Challenges and opportunities. Bioresour. Technol. 2015, 178, 178-186. [CrossRef] [PubMed]

71. Yue, Z.; Teater, C.; Liu, Y.; Maclellan, J.; Liao, W. A sustainable pathway of cellulosic ethanol production integrating anaerobic digestion with biorefining. Biotechnol. Bioeng. 2010, 105, 1031-1039. [CrossRef] [PubMed]

72. Ahn, H.K.; Smith, M.C.; Kondrad, S.L.; White, J.W. Evaluation of biogas production potential by dry anaerobic digestion of switchgrass-animal manure mixtures. Appl. Biochem. Biotechnol. 2010, 160, 965-975. [CrossRef] [PubMed]

73. Wu, J.; Cao, Z.; Hu, Y.; Wang, X.; Wang, G.; Zuo, J.; Wang, K.; Qian, Y. Microbial Insight into a Pilot-Scale Enhanced Two-Stage High-Solid Anaerobic Digestion System Treating Waste Activated Sludge. Int. J. Environ. Res. Public Health 2017, 14, 1483. [CrossRef] [PubMed]

74. Fierro, J.; Martínez, J.E.; Rosas, J.G.; Blanco, D.; Gómez, X. Anaerobic codigestion of poultry manure and sewage sludge under solid-phase configuration. Environ. Prog. Sustain. 2014, 33, 866-872. [CrossRef]

75. Smeller, L. Pressure-temperature phase diagrams of biomolecules. Biochim. Biophys. Acta 2002, 1595, e11-e29. [CrossRef] 
76. Mayumi, D.; Mochimaru, H.; Yoshioka, H.; Sakata, S.; Maeda, H.; Miyagawa, Y.; Ikarashi, M.; Takeuchi, M.; Kamagata, Y. Evidence for syntrophic acetate oxidation coupled to hydrogenotrophic methanogenesis in the high-temperature petroleum reservoir of Yabase oil field (Japan). Environ. Microbiol. 2011, 13, 1995-2006. [CrossRef] [PubMed]

77. Zeng, X.; Birrien, J.-L.; Fouquet, Y.; Cherkashov, G.; Jebbar, M.; Querellou, J.; Oger, P.; Cambon-Bonavita, M.-A.; Xiao, X.; Prieur, D. Pyrococcus CH1, an obligate piezophilic hyperthermophile: Extending the upper pressure-temperature limits for life. ISME J. 2009, 3, e873-e876. [CrossRef] [PubMed]

78. Takai, K.; Miyazaki, M.; Hirayama, H.; Nakagawa, S.; Querellou, J.; Godfroy, A. Isolation and physiological characterization of two novel, piezophilic, thermophilic chemolithoautotrophs from a deep-sea hydrothermal vent chimney. Environ. Microbiol. 2009, 11, e1983-e1997. [CrossRef] [PubMed]

79. Oger, P.M.; Jebbar, M. The many ways of coping with pressure. Res. Microbiol. 2010, 161, 799-809. [CrossRef] [PubMed]

80. Abe, F.; Horikoshi, K. The biotechnological potential of piezophiles. Trends Biotechnol. 2001, 19, $102-108$. [CrossRef]

81. Mayumi, D.; Dolfing, J.; Sakata, S.; Maeda, H.; Miyagawa, Y.; Ikarashi, M.; Tamaki, H.; Takeuchi, M.; Nakatsu, C.H.; Kamagata, Y. Carbon dioxide concentration dictates alternative methanogenic pathways in oil reservoirs. Nat. Commun. 2013, 4, 1998. [CrossRef] [PubMed]

82. Chen, Y.; Rößler, B.; Zielonka, S.; Wonneberger, A.M.; Lemmer, A. Effects of organic loading rate on the performance of a pressurized anaerobic filter in two-phase anaerobic digestion. Energies 2014, 7, 736-750. [CrossRef]

83. Lindeboom, R.E.F.; Fermoso, F.G.; Weijma, J.; Zagt, K.; Van Lier, J.B. Autogenerative high pressure digestion: Anaerobic digestion and biogas upgrading in a single step reactor system. Water Sci. Technol. 2011, 64, 647-653. [CrossRef] [PubMed]

84. Gregory, K.B.; Bond, D.R.; Lovley, D.R. Graphite electrodes as electron donors for anaerobic respiration. Environ. Microbiol. 2004, 6, 596-604. [CrossRef] [PubMed]

85. Bond, D.R.; Holmes, D.E.; Tender, L.M.; Lovley, D.R. Electrode-reducing microorganisms that harvest energy from marine sediments. Science 2002, 295, 483-485. [CrossRef] [PubMed]

86. Tender, L.M.; Reimers, C.E.; Stecher, H.A., III; Holmes, D.E.; Bond, D.R.; Lowy, D.A.; Pilobello, K.; Fertig, S.J.; Lovley, D.R. Harnessing microbially generated power on the seafloor. Nat. Biotechnol. 2002, $20,821$. [CrossRef] [PubMed]

87. Bond, D.R.; Lovley, D.R. Electricity production by Geobacter sulfurreducens attached to electrodes. Appl. Environ. Microbiol. 2003, 69, 1548-1555. [CrossRef] [PubMed]

88. Rotaru, A.E.; Shrestha, P.M.; Liu, F.; Shrestha, M.; Shrestha, D.; Embree, M.; Zengler, K.; Wardman, C.; Nevin, K.P.; Lovley, D.R. A new model for electron flow during anaerobic digestion: Direct interspecies electron transfer to Methanosaeta for the reduction of carbon dioxide to methane. Energy Environ. Sci. 2014, 7, 408-415. [CrossRef]

89. Hoban, D.J.; Van Den Berg, L. Effect of iron on conversion of acetic acid to methane during methanogenic fermentations. J. Appl. Bacteriol. 1979, 47, 153-159. [CrossRef] [PubMed]

90. Feng, Y.; Zhang, Y.; Quan, X.; Chen, S. Enhanced anaerobic digestion of waste activated sludge digestion by the addition of zero valent iron. Water Res. 2014, 52, 242-250. [CrossRef] [PubMed]

91. Zhang, Y.; Feng, Y.; Yu, Q.; Xu, Z.; Quan, X. Enhanced high-solids anaerobic digestion of waste activated sludge by the addition of scrap iron. Bioresour. Technol. 2014, 159, 297-304. [CrossRef] [PubMed]

92. Nevin, K.P.; Lovley, D.R. Lack of production of electron-shuttling compounds or solubilization of Fe (III) during reduction of insoluble Fe (III) oxide by Geobacter metallireducens. Appl. Environ. Microbiol. 2000, 66, 2248-2251. [CrossRef] [PubMed]

93. Kato, S. Influence of Anode Potentials on Current Generation and Extracellular Electron Transfer Paths of Geobacter Species. Int. J. Mol. Sci. 2017, 18, 108. [CrossRef] [PubMed]

94. Luo, L.; Xu, S.; Jin, Y.; Han, R.; Liu, H.; Lü, F. Evaluation of methanogenic microbial electrolysis cells under closed/open circuit operations. Environ. Technol. 2018, 39, 739-748. [CrossRef] [PubMed]

95. Dang, Y.; Holmes, D.E.; Zhao, Z.; Woodard, T.L.; Zhang, Y.; Sun, D.; Wang, L.Y.; Nevin, K.P.; Lovley, D.R. Enhancing anaerobic digestion of complex organic waste with carbon-based conductive materials. Bioresour. Technol. 2016, 220, 516-522. [CrossRef] [PubMed] 
96. Desai, M.; Madamwar, D. Anaerobic digestion of a mixture of cheese whey, poultry waste and cattle dung: A study of the use of adsorbents to improve digester performance. Environ. Pollut. 1994, 86, 337-340. [CrossRef]

97. Patel, V.; Patel, A.; Datta, M. Effects of adsorbents on anaerobic digestion of water hyacinth-cattle dung. Bioresour. Technol. 1992, 40, 179-181. [CrossRef]

98. Fagbohungbe, M.O.; Herbert, B.M.; Hurst, L.; Ibeto, C.N.; Li, H.; Usmani, S.Q.; Semple, K.T. The challenges of anaerobic digestion and the role of biochar in optimizing anaerobic digestion. Waste Manag. 2017, 61, 236-249. [CrossRef] [PubMed]

99. Borja, R.; Sánchez, E.; Duran, M.M. Effect of the clay mineral zeolite on ammonia inhibition of anaerobic thermophilic reactors treating cattle manure. J. Environ. Sci. Health Part A 1996, 31, 479-500. [CrossRef]

100. Lin, L.; Wan, C.; Liu, X.; Lei, Z.; Lee, D.J.; Zhang, Y.; Tay, J.H.; Zhang, Z. Anaerobic digestion of swine manure under natural zeolite addition: VFA evolution, cation variation, and related microbial diversity. Appl. Microbiol. Biotechnol. 2013, 97, 10575-10583. [CrossRef] [PubMed]

101. Ziganshina, E.E.; Belostotskiy, D.E.; Ilinskaya, O.N.; Boulygina, E.A.; Grigoryeva, T.V.; Ziganshin, A.M. Effect of the organic loading rate increase and the presence of zeolite on microbial community composition and process stability during anaerobic digestion of chicken wastes. Microb. Ecol. 2015, 70, 948-960. [CrossRef] [PubMed]

102. Angelidaki, I.; Petersen, S.P.; Ahring, B.K. Effects of lipids on thermophilic anaerobic digestion and reduction of lipid inhibition upon addition of bentonite. Appl. Microbiol. Biotechnol. 1990, 33, 469-472. [CrossRef] [PubMed]

103. Hansen, K.H.; Angelidaki, I.; Ahring, B.K. Improving thermophilic anaerobic digestion of swine manure. Water Res. 1999, 33, 1805-1810. [CrossRef]

104. Cuetos, M.J.; Morán, A.; Otero, M.; Gómez, X. Anaerobic co-digestion of poultry blood with OFMSW: FTIR and TG-DTG study of process stabilization. Environ. Technol. 2009, 30, 571-582. [CrossRef] [PubMed]

105. Cuetos, M.J.; Martinez, E.J.; Moreno, R.; Gonzalez, R.; Otero, M.; Gomez, X. Enhancing anaerobic digestion of poultry blood using activated carbon. J. Adv. Res. 2017, 8, 297-307. [CrossRef] [PubMed]

106. Capson-Tojo, G.; Moscoviz, R.; Ruiz, D.; Santa-Catalina, G.; Trably, E.; Rouez, M.; Crest, M.; Steyer, J.P.; Bernet, N.; Delgenès, J.P.; et al. Addition of granular activated carbon and trace elements to favor volatile fatty acid consumption during anaerobic digestion of food waste. Bioresour. Technol. 2018, 260, 157-168. [CrossRef] [PubMed]

107. Moreno, R.; Martínez, E.J.; Escapa, A.; Martínez, O.; Díez-Antolínez, R.; Gómez, X. Mitigation of Volatile Fatty Acid Build-Up by the Use of Soft Carbon Felt Electrodes: Evaluation of Anaerobic Digestion in Acidic Conditions. Fermentation 2018, 4, 2. [CrossRef]

108. De Vrieze, J.; Gildemyn, S.; Arends, J.B.; Vanwonterghem, I.; Verbeken, K.; Boon, N.; Verstraete, W.; Tyson, G.W.; Hennebel, T.; Rabaey, K. Biomass retention on electrodes rather than electrical current enhances stability in anaerobic digestion. Water Res. 2014, 54, 211-221. [CrossRef] [PubMed]

109. Liu, W.; Cai, W.; Guo, Z.; Wang, L.; Yang, C.; Varrone, C.; Wang, A. Microbial electrolysis contribution to anaerobic digestion of waste activated sludge, leading to accelerated methane production. Renew. Energy 2016, 91, 334-339. [CrossRef]

110. Feng, Y.; Zhang, Y.; Chen, S.; Quan, X. Enhanced production of methane from waste activated sludge by the combination of high-solid anaerobic digestion and microbial electrolysis cell with iron-graphite electrode. Chem. Eng. J. 2015, 259, 787-794. [CrossRef]

111. Bo, T.; Zhu, X.; Zhang, L.; Tao, Y.; He, X.; Li, D.; Yan, Z. A new upgraded biogas production process: Coupling microbial electrolysis cell and anaerobic digestion in single-chamber, barrel-shape stainless steel reactor. Electrochem. Commun. 2014, 45, 67-70. [CrossRef]

112. Reddy, P.M.K.; Mahammadunnisa, S.K.; Ramaraju, B.; Sreedhar, B.; Subrahmanyam, C. Low-cost adsorbents from bio-waste for the removal of dyes from aqueous solution. Environ. Sci. Pollut. Res. 2013, 20, 4111-4124. [CrossRef] [PubMed]

113. Kyzas, G.Z.; Kostoglou, M. Green adsorbents for wastewaters: A critical review. Materials 2014, 7, $333-364$. [CrossRef] [PubMed]

114. Contescu, C.; Adhikari, S.; Gallego, N.; Evans, N.; Biss, B. Activated Carbons Derived from High-Temperature Pyrolysis of Lignocellulosic Biomass. Carbon 2018, 4, 51. [CrossRef] 
115. Visioli, G.; Conti, F.D.; Menta, C.; Bandiera, M.; Malcevschi, A.; Jones, D.L.; Vamerali, T. Assessing biochar ecotoxicology for soil amendment by root phytotoxicity bioassays. Environ. Monit. Assess. 2016. [CrossRef] [PubMed]

116. Si, L.; Xie, Y.; Ma, Q.; Wu, L. The Short-Term Effects of Rice Straw Biochar, Nitrogen and Phosphorus Fertilizer on Rice Yield and Soil Properties in a Cold Waterlogged Paddy Field. Sustainability 2018, 10, 537. [CrossRef]

117. Seehausen, M.L.; Gale, N.V.; Dranga, S.; Hudson, V.; Liu, N.; Michener, J.; Thurston, E.; Williams, C.; Smith, S.M.; Thomas, S.C. Is There a Positive Synergistic Effect of Biochar and Compost Soil Amendments on Plant Growth and Physiological Performance? Agronomy 2017, 7, 13. [CrossRef]

118. De la Rosa, J.M.; Paneque, M.; Hilber, I.; Blum, F.; Knicker, H.E.; Bucheli, T.D. Assessment of polycyclic aromatic hydrocarbons in biochar and biochar-amended agricultural soil from Southern Spain. J. Soils Sediments 2016, 16, 557-565. [CrossRef]

119. Dieguez-Alonso, A.; Funke, A.; Anca-Couce, A.; Rombolà, A.G.; Ojeda, G.; Bachmann, J.; Behrendt, F. Towards Biochar and Hydrochar Engineering-Influence of Process Conditions on Surface Physical and Chemical Properties, Thermal Stability, Nutrient Availability, Toxicity and Wettability. Energies 2018, 11, 496. [CrossRef]

120. Figueiredo, C.; Lopes, H.; Coser, T.; Vale, A.; Busato, J.; Aguiar, N.; Novotny, E.; Canellas, L. Influence of pyrolysis temperature on chemical and physical properties of biochar from sewage sludge. Arch. Agron. Soil Sci. 2018, 64, 881-889. [CrossRef]

121. Luo, C.; Lü, F.; Shao, L.; He, P. Application of eco-compatible biochar in anaerobic digestion to relieve acid stress and promote the selective colonization of functional microbes. Water Res. 2015, 68, 710-718. [CrossRef] [PubMed]

122. Cai, J.; He, P.; Wang, Y.; Shao, L.; Lü, F. Effects and optimization of the use of biochar in anaerobic digestion of food wastes. Waste Manag. Res. 2016, 34, 409-416. [CrossRef] [PubMed]

123. Gómez, X.; Meredith, W.; Fernández, C.; Sánchez-García, M.; Díez-Antolínez, R.; Garzón-Santos, J.; Snape, C.E. Evaluating the effect of biochar addition on the anaerobic digestion of swine manure: Application of Py-GC/MS. Environ. Sci. Pollut. Res. 2018, 25, 25600-25611. [CrossRef] [PubMed]

124. Lü, F.; Luo, C.; Shao, L.; He, P. Biochar alleviates combined stress of ammonium and acids by firstly enriching Methanosaeta and then Methanosarcina. Water Res. 2016, 90, 34-43. [CrossRef] [PubMed]

125. Shen, Y.; Linville, J.L.; Urgun-Demirtas, M.; Schoene, R.P.; Snyder, S.W. Producing pipeline-quality biomethane via anaerobic digestion of sludge amended with corn stover biochar with in-situ $\mathrm{CO}_{2}$ removal. Appl. Energy 2015, 158, 300-309. [CrossRef]

126. Meyer-Kohlstock, D.; Haupt, T.; Heldt, E.; Heldt, N.; Kraft, E. Biochar as additive in biogas-production from bio-waste. Energies 2016, 9, 247. [CrossRef]

127. Martínez, E.J.; Rosas, J.G.; Sotres, A.; Moran, A.; Cara, J.; Sánchez, M.E.; Gómez, X. Codigestion of sludge and citrus peel wastes: Evaluating the effect of biochar addition on microbial communities. Biochem. Eng. J. 2018, 137, 314-325. [CrossRef]

128. Viggi, C.C.; Simonetti, S.; Palma, E.; Pagliaccia, P.; Braguglia, C.; Fazi, S.; Baronti, S.; Navarra, M.A.; Pettiti, I.; Koch, C.; et al. Enhancing methane production from food waste fermentate using biochar: The added value of electrochemical testing in pre-selecting the most effective type of biochar. Biotechnol. Biofuels 2017. [CrossRef]

129. Monlau, F.; Francavilla, M.; Sambusiti, C.; Antoniou, N.; Solhy, A.; Libutti, A.; Zabaniotou, A.; Barakat, A.; Monteleone, M. Toward a functional integration of anaerobic digestion and pyrolysis for a sustainable resource management. Comparison between solid-digestate and its derived pyrochar as soil amendment. Appl. Energy 2016, 169, 652-662. [CrossRef]

130. Hübner, T.; Mumme, J. Integration of pyrolysis and anaerobic digestion-use of aqueous liquor from digestate pyrolysis for biogas production. Bioresour. Technol. 2015, 183, 86-92. [CrossRef] [PubMed]

131. Salman, C.A.; Schwede, S.; Thorin, E.; Yan, J. Predictive modelling and simulation of integrated pyrolysis and anaerobic digestion process. Enrgy Procedia 2017, 105, 850-857. [CrossRef]

(C) 2018 by the authors. Licensee MDPI, Basel, Switzerland. This article is an open access article distributed under the terms and conditions of the Creative Commons Attribution (CC BY) license (http:/ / creativecommons.org/licenses/by/4.0/). 